\title{
Ensuring the security of health care in conflict settings: an urgent global health concern
}

\author{
Jason W. Nickerson RRT PhD
}

CMAJ Podcasts: author interview at soundcloud.com/cmajpodcasts/conflict-health

$\mathrm{O}$ n Feb. 19, 2014, armed fighters entered the Malakal Teaching Hospital run by Médecins Sans Frontières in South Sudan, robbed patients and their families of cash and mobile phones, and shot those who had nothing to give, killing 14 patients who were lying in their hospital beds. ${ }^{1}$ In Syria, not only has the neutrality of medical personnel, hospitals and patients been ignored, these individuals and facilities have become strategic targets in a systematic campaign of violence that, according to the United Nations, has seen "... government forces and affiliated militias interfere with and instrumentalise medical care to further strategic and military aims." ${ }^{2}$ These acts of brutality are two examples of a global problem for which there are few solutions: in many parts of the world, health care is in danger.

Armed conflicts, internal disturbances and other types of unrest create a generalized state of insecurity that often makes maintaining a minimally functional health system nearly impossible. Health facilities are destroyed, looted or forced to close or become isolated from the populations they serve. ${ }^{3}$ Patients may be attacked or robbed, and health workers threatened or kidnapped. ${ }^{4}$ Policies and laws may be enacted to criminalize or restrict the provision of medical care to those opposing the state. ${ }^{5}$ Ambulances are frequently delayed or are targets of attacks and hijackings, which limits the effectiveness of referral systems. ${ }^{6}$

There have been growing calls to strengthen the right to health in conflict, and for non-state actors to be held accountable for attacks on health workers through existing human rights mechanisms. ${ }^{5}$ The Geneva Conventions, customary international humanitarian law and other treaties include provisions that clearly identify attacks on health workers and patients as a violation of international law. Regrettably, these are routinely ignored or are not translated into national legislation in the countries where these acts occur. ${ }^{7}$ Meanwhile, several international bodies have passed resolutions attempting to strengthen these mechanisms, including the 2011 United Nations Security Council resolution 1998, which declared hospitals off limits for armed groups and military activities and allows public reporting of the parties who attack them. ${ }^{8}$ Civil society coalitions, such as the Safeguarding Health in Conflict Coalition, have demanded monitoring, reporting and accountability for such attacks, while raising the issue politically and within academic communities.

These interventions are necessary, but more must be done. Attacks on health systems often have a strategic advantage as a tactic of war, are rarely prosecuted nationally and may even have been committed by the government that would, theoretically, be prosecuting them. Invoking the jurisdiction of the International Criminal Court in prosecuting these attacks may, therefore, be appropriate in these circumstances. ${ }^{9}$

For humanitarian agencies operating in violent settings, the available interventions are challenging: openly reporting attacks places them at risk of reprisal; barricading or reinforcing hospitals to become fortresses is inconsistent with the need to be accessible and to be viewed as a community, rather than a military, asset; arming humanitarian agencies blurs the boundaries between the militarization and neutrality of aid; and not operating in conflict zones denies the world's most vulnerable people of basic health services.

\section{KEY POINTS}

- Attacks on health workers, health facilities and patients are a common threat to medical care in conflict zones.

- The Geneva Conventions, customary international humanitarian law and other treaties clearly identify attacks on health workers and patients as a violation of international law.

- However, the recommendations of such bodies are poorly enforced in many jurisdictions.

- Carefully collected data are needed to further our knowledge of attacks and to inform the development of countermeasures to improve programs in different settings and contexts. 
The use of military forces to protect civilians and humanitarian agencies has garnered particular attention over the past decade through the controversial concept of the "responsibility to protect," or R2P. This concept is controversial for several reasons. Chief among them are the lack of automatic or consistent protection from foreign military forces, and the resistance by many humanitarian agencies to support R2P on the basis that it compromises their neutrality and impartiality by providing legitimacy to the objectives of one of the warring parties. ${ }^{10}$

A clear need exists to strengthen an understanding of the nature and causes of violent events directed toward health care providers, and the interventions that have been effective in mitigating them. The International Committee of the Red Cross has taken the lead on this, conducting a two-year, anonymized, 16-country study that documented 1342 reports of 655 separate events of violence or threats affecting health care. ${ }^{4}$ The committee then convened stakeholder meetings to identify best practices and potential solutions for ensuring the continued provision of medical care in conflict zones. In 2012, the World Health Assembly passed a resolution (WHA65.20) calling for the World Health Organization to improve the systematic documentation of these attacks and to generate an evidence base for greater protection and advocacy. ${ }^{11}$

In addition to the systematic reporting of the scope and incidence of violent attacks and threats directed toward health workers, a more nuanced understanding of the nature and causes of these events is needed to better contextualize their impact and the appropriate responses. Operational research to systematically describe the impact of violent events on patients, health workers and health systems is needed to understand more precisely what occurs and what interventions have been implemented to mitigate these effects, both successfully and unsuccessfully, as well as their implications. Developing a detailed understanding of what takes place at checkpoints or during armed entries to hospitals, for example, provides a needed context through which interventions can be assessed. The synthesis of these experiences is essential for weighing the risks and benefits of interventions. Although some interventions may be easily implemented, such as placing plastic sheeting on windows to absorb shrapnel from bomb blasts, other interventions such as decisions to stockpile medicines have associated risks (e.g., looting).

More than merely documenting experiences, what is needed is the development of a decision aid based on pragmatic anecdotal, experiential and often unpublished evidence to guide the maintenance of the essential functions of health systems during violent events. This must be matched by strong advocacy and engagement of civil society organizations to ensure that those who commit crimes against health workers and patients are held to account. The medical community must pressure governments to pursue international justice and demand accountability for war crimes against medical workers, in solidarity with colleagues and patients whose safety is directly at risk.

\section{References}

1. Medical care under fire in South Sudan. Toronto: Médecins Sans Frontières Canada; 2014. Available: www.msf.ca/en/article/ medical-care-under-fire-south-sudan (accessed 2014 Mar. 24)

2. Assault on medical care in Syria [A/HRC/24/CRP.2]. Geneva: United Nations Human Rights Council; 2013. Available: www.ohchr.org/EN/HRBodies/HRC/RegularSessions/Session24 /Documents/A-HRC-24-CRP-2.doc (accessed 2014 Mar. 17).

3. Dewachi O, Skelton M, Nguyen V-K, et al. Changing therapeutic geographies of the Iraqi and Syrian wars. Lancet 2014;383: 449-57.

4. Health care in danger: a sixteen-country study. Geneva: International Committee of the Red Cross; 2011. Available: www.icrc.org /eng/resources/documents/report/hcid-report-2011-08-10.htm (accessed 2014 Mar. 24).

5. Report of the Special Rapporteur on the right of everyone to the enjoyment of the highest attainable standard of physical and mental health. Geneva: United Nations Human Rights Office of the High Commissioner for Human Rights; 2014.

6. Coupland R. Security of health care and global health. $N$ Engl J Med 2013;368:1075-6.

7. Rubenstein LS, Bittle MD. Responsibility for protection of medical workers and facilities in armed conflict. Lancet 2010;375: 329-40.

8. Resolution 1998 (2011) [S/RES/1998(2011)]. Geneva: United Nations Security Council; 2011. Available: www.un.org/en/ga /search/view_doc.asp?symbol=S/RES/1998(2011) (accessed 2014 Mar. 17).

9. Protection of health workers, patients and facilities in times of violence. Baltimore: Center for Public Health and Human Rights, Johns Hopkins Bloomberg School of Public Health; 2013. Available: www.jhsph.edu/research/centers-and-institutes /center-for-public-health-and-human-rights/_pdf/BellagioReport -03192014.pdf (accessed 2014 Aug. 20).

10. Weissman F. Not in our name: why Médecins Sans Frontières does not support the "responsibility to protect." Crim Justice Ethics 2010;29:194-207.

11. WHO's response, and role as the health cluster lead, in meeting the growing demands of health in humanitarian emergencies [Resolution WHA65.20]. Sixty-fifth World Health Assembly; Geneva; 2012 May 21-26. Available: http://apps.who.int/gb/ebwha/pdf files/WHA65/A65_R20-en.pdf (accessed 2015 Apr. 21).

Affiliation: Bruyère Research Institute, Ottawa, Ont. 